\title{
Üniversite Öğrencilerinin Nomofobi Düzeyini Etkileyen Faktörler ve Ders Performansları Üzerinde Nomofobinin Etkisi
}

DOI: 10.26466/opus.650312

*

\section{Haydar Hoşgör *}

* Öğr. Gör. Dr., Uşak Üniversitesi, Sağlık Hizmetleri MYO, Uşak/Türkiye E-Posta: haydar.hosgor@usak.edu.tr

ORCID: $\underline{0000-0002-1174-1184}$

Öz

Bu çalışmada, üniversite öğrencilerinin nomofobi düzeylerini etkileyen faktörlerin saptanması ve onların ders performansları üzerinde nomofobi etkisinin araştırılması amaçlanmıştır. Tanımlayııı türdeki bu çalışmanın katılımcılarımı, 2017-2018 öğretim yılı bahar döneminde İstanbul'da să̆llkla ilgili farklı bölümlerde okuyan 258 üniversite öğrencisi oluşturmuştur. Verilerin toplanmasında Yıldırım ve Correia (2015) tarafindan geliştirilmiş ve Yıldırım vd. (2016) tarafından Türkçe'ye uyarlanmış Nomofobi Ölçeği kullanılmıştır. Verilerin analizinde betimsel istatistikler, doğrulayıcı faktör analizi ile yapısal eşitlik modelinden faydalanılmıştır. Öğrencilerin nomofobi düzeyi $(3,23 \pm 0,81)$ ortalamanın üzerinde hesaplanmıştır. Akıllı telefonun günlük kontrol edilme sıklı̆̆ı ( $\beta=0,35)$, şarj cihazı taşıma durumu ( $\beta=-$ $0,12)$, uyanır uyanmaz akıllı telefonun kontrol edilmesi durumu $(\beta=-0,29)$, akıllı telefon üzerinden sosyal medyanın günlük kullanım süresi $(\beta=0,15)$ değişkenlerinin, öğrencilerin nomofobi düzeyini anlamlı etkilediğgi saptanmıştır. Bir diğer ifadeyle öğrencilerin nomofobi düzeylerinin; akıllı telefon ve sosyal medya kullanım nitelikleri tarafından \%30 oranında yordandığı hesaplanmıştır. Nomofobi gizil değişkeni ve onun alt boyutların teşkil eden gözlem değişkenleri arasındaki tüm yolların da pozitif ve anlamlı olduğu belirlenmiştir. Öğrencilerin dersi derste dinleme $(\beta=-0,22)$ ve derse katılım düzeyleri $(\beta=-0,13)$ üzerinde nomofobinin negatif ve anlaml bir etkisi bulunmuştur. Özetle öğrencilerin nomofobi düzeyleri arttıkça ders dinleme ve derse katılım performansları düşmektedir.

Anahtar Kelimeler: Nomofobi, Mobil Teknolojiler, Akıllı Telefon Bağımlılı̆̆ı, Ders Performansı, Üniversite Öğrencileri, 


\title{
The Factors Influencing Nomophobia Level of University Students and the Effect of Nomophobia on the Course Performances
}

\begin{abstract}
In this study, it was aimed to determine the factors that affect the nomophobia levels of the students and the investigation of the effect of nomophobia on their lesson performances. The participants of this descriptive study consists of 258 students who are studying in different department related to health in Istanbul in the 2017-2018 academic year spring semester. In the data collection, the Nomophobia Questionnaire, which was developed by Yildirm and Correia (2015) and adapted to Turkish by Yildirtm et al. (2016), was used. In the data analysis, descriptive statistics, confirmatory factor analysis and structural equation model were used. The nomophobia levels of the students is calculated above the average $(3,20 \pm 0,81)$. It was determined that the variables of the frequency of the smartphone's daily control $(\beta=0,35)$, carrying the status of the charger $(\beta=-0,12)$, controlling the status of the smartphone as soon as waking up $(\beta=-0,29)$, and daily use time of social media by means of the smartphone $(\beta=0,15)$ were affecting the nomophobia levels of students significant. In other words, the nomophobia levels of the students were predicted with $30 \%$ rate by the qualities of the smartphone and social media usage. All pathways between the nomophobia latent variable and the observational variables constituting its subdimensions were also found to be positive and significant. There was a negative and significant effect of nomophobia on students' listening to the course $(\beta=-0.22)$ and its participation levels $(\beta=-0.13)$. In summary, as students' nomophobia levels increase, their course performances decrease.
\end{abstract}

Keywords: Nomophobia, Mobile Technologies, Smartphone Addiction, Lesson Performance, University Students 


\section{Giriş}

Günümüzün modern ve dijitalleşen dünyasında anksiyete yaşamın kaçınılmaz bir stres kaynağıdır. Akıllı telefondan mahrum kalma korkusu olarak bilinen nomofobi ise, stres kaynakları listesine yeni eklenen bir kavramdır. Bir diğer ifadeyle akıllı telefon bağımlılı̆̆ olarak literatürde yer alan nomofobi, sanal iletişimi sağlayan teknolojik gelişmelerin bir sonucudur (Pavithra vd., 2015, s.340). Özellikle teknolojik açıdan cep telefonları, son yıllarda olağanüstü bir gelişim kaydederek, bireylerin günlük yaşamlarının vazgeçilmez bir parçası halini almıştır (Argumosa-Villar vd., 2017, s.127). Dasgupta vd. (2017, s.199); önemli teknolojik gelişmeler ve akıllı telefonların azalan maliyetleri dolayısıyla dünya genelinde mobil bağımlılığın giderek artmakta olduğunu ve buna gerekçe olarak da 2012'nin üçüncü çeyreğinde dünya genelinde bir milyar akıllı telefon kullanıldığını belirtmektedir.

"We are Social" tarafından her yıl yayınlanan "Digital in 2018" Raporu'nda; yaklaşık 7,6 milyarlık dünya nüfusunun \%68'inin akıllı telefon kullandığı, yaklaşık \%53'ünün internet kullandığı, \%42'sinin sosyal medyayı aktif olarak kullandığı ve yaklaşık \%39'unun ise sosyal medyaya akıllı telefonları vasitasıyla bağlandığı raporlanmıştır (We are Social, 2018). Yine aynı raporda 81,3 milyon nüfusa sahip olan Türkiye'de ise ilgili oranların sirayla; $\% 90, \% 67, \% 63$ ve $\% 54$ olduğu belirtilmiştir.

The Deloitte Times (2018)'in Raporu'nda; Türkiye'deki mobil kullanıcıların günde ortalama $78 \mathrm{kez}$ (13 dakikada bir) akıllı telefonlarını kontrol ettikleri ve uyandıktan sonraki ilk 15 dakika içerisinde akıllı telefonlarına bakma oranlarının \%79 olduğu vurgulanmıştır. Ayrıca Türkiye'deki mobil telefon kullanıcılarının gün içerisinde akıllı telefonlarına bakma ortalamalarının Avrupa'ya kıyasla 1,5 kat daha fazla olduğunun altı çizilmiştir. Bu veriler, Türkiye örnekleminde nomofobik eğilimin giderek artmakta olduğu şeklinde yorumlanabilir. Yukarıda yer verilen raporlara ilişkin verilerden de anlaşıldığ üzere, tüm dünyada olduğu gibi Türkiye'de de nüfusun büyük bir çoğunluğu nomofobik etkilere oldukça açıktır. Nitekim Kanmani vd. (2017, s.6) de, dünya genelinde milyonlarca insanın nomofobiden muzdarip olduğunu ve bundan en fazla etkilenen grubun 18-24 yaş aralığındaki genç ergenlerden meydana geldiğini ifade etmektedir. 
Choliz (2010, s.373); akıllı telefonların, 21. yüzyılın uyuşturucu olmayan bağımlılıklardan birisi olarak görülmeye başlandığına değinmektedir. Bir diğer taraftan Gezgin vd. (2017, s.5) ise bu bağımlılı̆̆ın teknoloji kaynaklı mı yoksa sendrom mu olduğu hususuna dikkat çekmektedir. Teknoloji kökenli bir bağımlılık olarak ele alındığında, tipik bir nomofobik bireyin profilişu şekilde sıralanabilir: gelen arama ve bildirimleri takıntılı düzeyde kontrol eder, her nereye giderse gitsin telefonunu yanından ayırmaz, uygunsuz zamanlarda bile telefonunu kullanır, yanında sürekli şarj cihazı taşır, uyanır uyanmaz akıllı telefonunu kontrol eder, geceleri telefonunu kapatmaz ve akıllı telefonu ile yatakta zaman geçirir (Kanmani vd., 2017, s.6).

\section{Kavramsal Çerçeve}

Günümüz yüzyılının hastalığı olarak görülen nomofobi, akıllı telefon veya bilgisayar ile bağlantının kesilmesi durumunda maruz kalınan genel bir gerginlik ve huzursuzluk halidir (King vd., 2010, s.52). İngilizce' de nomophobia (no mobilephone phobia) sözcügünün kısaltılmasından türetilmiş (RosalesHuamani vd., 2019: 2) olan nomofobi (akıllı telefondan mahrum kalma korkusu), modern çağın yeni fobisi olarak ele alınmaktadır. Amerikan Psikiyatri Birliği tarafından yayınlanan Ruhsal Bozuklukların Tanısal ve Sayımsal El Kitab1 (Diagnostic \& Statistical Manual of Mental Disorders)'nın beşinci bas1mında bir hastalık olarak yer almamış olmasına rağmen nomofobinin, ilgili yayının bir önceki basımında özel bir korku türü olarak yer alması gerektiği önerilmiştir (Bragazzi ve Puente, 2014).

Bireyleri temel ihtiyaçlarını tatmin noktasında yetkin kılan akıllı telefonlar, belirgin yararlarının yanı sıra bazı problemlere de sebep olabilmektedir (Yıldırım ve Correia, 2015, s.130). Buna paralel olarak Alosaimi vd. (2016, s.676) de; bilgiye kolay erişim, sosyal bağlantı ve çoklu iletişim ortamları gibi akıllı telefonların pek çok faydalarının yanı sıra, bu türden mobil cihazların kullanımı dolayısıyla maruz kalınan sağlık sorunlarına işaret etmektedir. 2367 üniversite öğrencisinin katılımıyla gerçekleştirilen ilgili çalışmada; akıllı telefon kullanmanın bir sonucu olarak katılımcıların \%43'ünün uyku saatlerinin azaldığı ve ertesi gün enerjilerinin düştüğü, \%30'unun ise daha sağlıksız bir yaşam tarzına sahip olduğu saptanmıştır. Benzer şekilde mevcut alan yazında akıllı telefon kullanım sıklığıyla; mobil telefon bağımlılığı, kaygı, stres ve depresyon arasında pozitif ilişkilerin görüldüğünü raporlayan pek çok 
araştırma (Roberts ve Pirog, 2013; Nikhita vd., 2015; Billieux vd., 2015; Takao vd., 2009) mevcuttur. Özellikle genç neslin günlük yaşamını fiziksel ve ruhsal açıdan olumsuz etkileyen nomofobinin (Broughton, 2015), parmak yapısını bozduğu, dikkat dağınıklığına yol açtığı, uyku kalitesine zarar verdiği ve yabanclaşmayı tetiklediği (King vd., 2013; Ming vd., 2006) bilinmektedir.

Yıldırım ve Kişioğlu (2018, s.476) akıllı telefonların problemli kullanımının; boyun ağrısı, depresyon, hoşgörü eksikliği, sosyal izolasyon, yalnızlık, düşük öz saygı, yaşam beklentisinde azalma ve aile içi ilişkilerin bozulması gibi birçok sorunla ilintisine değinmektedirler. King vd. (2014, s.29)'nin deney grubu (açı alan korkusu yaşayan 50 panik ataklı) ve kontrol grubu (psikiyatrik rahatsızlığı olmayan 70 kişi) vasıtasıyla gerçekleştirdikleri çalışmada; kontrol grubuna kıyasla deney grubundaki nomofobik katılımclların kayg,, taşikardi, solunum değişiklikleri, titreme, terleme, panik ve depresyon düzeylerinde önemli artsşlar görüldügü ortaya konulmuştur.

Kwon vd. (2013, s.1); akıllı telefonlarından video izleyerek trafik işaretlerine dikkat etmeksizin yürüyen yayaların yaşamlarını kaybedebildiğine, araç kullanırken akıllı telefonlarıyla meşgul olan sürücülerin ölümlü kazalara karışabildiğine, ilköğretim çağındaki çocukların oyun ve videolar dolayısıyla akıllı telefon bağımlısı haline dönüşebildiğine ve bu sebeple sınıf içi ders konsantrasyonlarında düşüş yaşanabildiğine atıf yapmaktadırlar. Ünal (2015); casus yazılımlar ile akıllı telefon şifrelerinin ele geçirilip insanların özel yaşamlarına müdahale edilebilmesi gibi çeşitli sorunların varlığını vurgulamaktadır. Sert vd. (2019, s.2) ise bu sorunlara ek olarak baş ve sırt ağrısı, görme bozukluğu, obezite, karpal tünel sendromu, davranış bozuklukları, umutsuzluk, güvensizlik, zihinsel yorgunluk, aleksitimi, düşük iş performansı ve verimsiz zaman yönetiminin varlığına dikkat çekmektedir.

Bilgisayar laboratuvarlarına erişimin daha kolay olduğu üniversite kampüslerinde nomofobi yaygınlığının daha yüksek olduğunu; hatta ortaokul ve lise öğrencilerinde de görüldüğünü vurgulayan Wallace (2014, s.12)'nin görüşlerinden yola çıkarak, nomofobinin ders performansı ve akademik başarı üzerindeki etkilerine odaklanmak önemli olabilir. Zira, özellikle sınıf ortaminda cep telefonu kullanımının toplumda kabul edilemez bir durum olduğu, aynı ortamı paylaşan diğer bireylerin dikkatini dağıttığı ve şikâyetlere sebep olduğu bilinmektedir (Campbell, 2004). Çünkü Türkiye gibi, öğrencilerin akademik başarısı veya başarısızlığının kişi, aile ve toplum nezdinde kıymetli olduğu ülkelerde, toplumsal gelişim için başarılı ve kalifiye insan 
kaynağının varlı̆̆ı en temel güç (Dikmen, 2016) olarak değerlendirilmektedir. Ulusal literatürde kısıtlı sayıda araştırma olmasına rağmen, uluslararası literatürde öğrencilerin akademik performansları ile nomofobi ilişkisini ele alan çok sayıda çalışmanın varlığı da bu değerlendirmeyi destekler niteliktedir. Örneğin Ahmed vd. (2019)'nin 157 fizyoterapi öğrencisiyle yaptığı çalışmada, akademik performans ile nomofobi arasında anlamlı ve negatif yönlü bir ilişki tespit edilmiştir. Louragli vd. (2018) tarafından 541 ergenle yürütülen araştırmada nomofobi ile okul performansı arasında ters yönlü bir ilişki saptanmış ve bu ilişkide akıllı telefonların rolünün dizüstü bilgisayarlara kıyasla daha etkili olduğu sonucuna erişilmiştir. Pakistan' da tıp eğitimi gören $308 \mathrm{klz}$ öğrencinin katılımıyla gerçekleştirilen bir çalışmada (Aman vd., 2015); öğrencilerin \%81'inin akıllı telefon aldıktan sonra günlük rutinlerinin değiştiği, \%53'ünün ise akademik performanslarının olumsuz etkilendiği rapor edilmiştir. Mendoza vd. (2018); kısa bir derste akıllı cep telefonuna sahip olmanın, derste 10-15 dakika öğrenme ve dikkat üzerinde en büyük etkiye sahip olduğunu belirtmiştir. 554 diş hekimi adayının katılımıyla Prasad vd. (2017) tarafından yürütülen bir diğer çalışmada ise; öğrencilerin yaklaşık \%39,5'i eğer akıllı cep telefonları ile daha fazla zaman geçirirse, mesleki sınavlardan daha düşük not alacaklarını belirtmişlerdir.

\section{Yöntem}

\section{Çalışmanın Amacı ve Önemi}

Bu çalışmanın temel amacını; üniversite öğrencilerinin nomofobi düzeylerini etkileyen faktörlerin belirlenmesi ve öğrencilerin ders performansları üzerinde nomofobi etkisinin araştırılması oluşturmaktadır. Bu çalışmanın gerek sağlıkla ilgili bölümlerde eğitim gören bir örneklem grubunda gerçekleştirilmiş olması, gerekse de nomofobinin öncülleri ve ders performansı üzerinde nomofobi etkisini ulusal düzeyde irdeleyen sınırlı sayıdaki çalışmalardan biri olması, alandaki mevcut boşluğun giderilmesi bakımından önem teşkil etmektedir. Ayrıca öğrencilerin nomofobi düzeyleri üzerinde etkili olduğu düşünülen değişkenlerin belirlenmesi, dolaylı yoldan ders performansları üzerinde olumsuzluk teşkil eden nedenlerin anlamlandırılması ve gerekli önlemlerin alınması noktasında da anahtar bir role sahip olabilmektedir. 


\section{Çalışmanın Modeli ve Hipotezleri}

Çalışmanın amacı doğrultusunda tasarlanan araştırma modeli (Şekil 1), aşağıdaki hipotezler vasıtasıyla test edilmektedir.

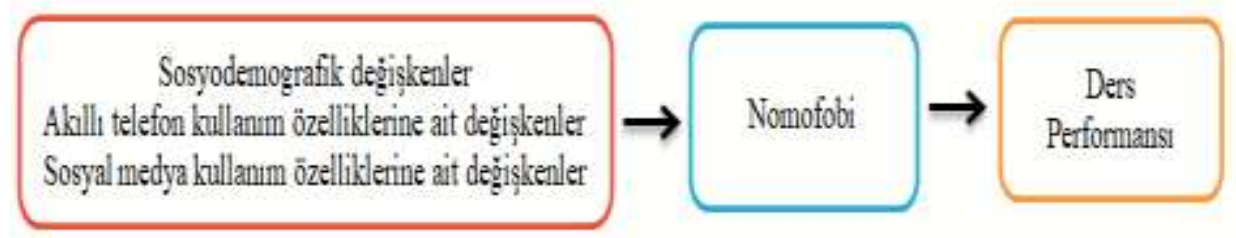

Şekil 1. Araştırma Modeli

- H1: Cinsiyet, nomofobi düzeyini etkiler.

- $\mathbf{H}_{2}$ : Yaş, nomofobi düzeyini etkiler.

- $\mathbf{H}_{3}$ : Bölüm, nomofobi düzeyini etkiler.

- H4: Akıllı telefonu günlük kontrol etme sıklığı, nomofobi düzeyini etkiler.

- H5: Şarj cihazı taşıma durumu, nomofobi düzeyini etkiler.

- H6: Uyanır uyanmaz akıllı telefon kontrol etme durumu, nomofobi düzeyini etkiler.

- $\mathbf{H}_{7}$ : Yatağa akıllı telefonla girme durumu, nomofobi düzeyini etkiler.

- Hs: Akılli telefonu gece kapatma durumu, nomofobi düzeyini etkiler.

- Hy: Sosyal medyada sahip olunan hesap sayısı, nomofobi düzeyini etkiler.

- Hı: Akıllı telefon üzerinden sosyal medyanın günlük kullanım süresi, nomofobi düzeyini etkiler.

- H11: Nomofobi düzeyi, bilgiye ulaşamama boyutunu etkiler.

- H12: Nomofobi düzeyi, cihazdan yoksunluk boyutunu etkiler.

- H13: Nomofobi düzeyi, iletişini kaybetme boyutunu etkiler.

- H14: Nomofobi düzeyi, çevrimiçi olamama boyutunu etkiler.

- H15: Nomofobi düzeyi, dersi derste dinleme düzeyini etkiler.

- H16: Nomofobi düzeyi, derse katılım düzeyini etkiler. 


\section{Çalışmanın Türü ve Katılımcıları}

$\mathrm{Bu}$ araştırma tanımlayıı bir desende tasarlanmıştır. Tanımlayı ı çalışmaların amacl; olgu ve nesnelerin mevcut durumunu ortaya koymaktır. Bu türden tanımlayıcı tasarımlarda, toplanan verilerin analiz edilerek belirli sonuçlara erişilmesi gerekmektedir (Altunışık vd., 2010, s.69).

Kolayda örnekleme yönteminin kullanıldığı çalışmanın katılımcılarını, İstanbul'da sağlıkla ilgili farklı bölümlerde (hemşirelik, ebelik, ilk ve acil yardım, anestezi, fizyoterapi, radyoterapi) okuyan ön lisans ve lisans düzeyindeki üniversite öğrencileri oluşturmaktadır. Gönüllülük esasına dayanan çalışmada, öğrencilerin kendilerine ait internet paketi olan bir akıllı telefona ve sosyal medya hesabına sahip olmaları ön koşulu aranmıştır. Araştırma kapsamında 279 veri toplanmış; fakat uygun şekilde doldurulmayan 21 adet anketin elimine edilmesi sonucu 258 veri araştırmaya dâhil edilmiştir. Araştırmaya katılan öğrencilerin sosyo-demografik göstergelerine ek olarak akıllı telefon ve sosyal mecra kullanım niteliklerine ilişkin veriler de Tablo 1'de sunulmaktadır.

\section{Veri Toplama Araçları}

Katılımcıların nomofobi düzeylerini ölçmek için Yıldırım ve Correia (2015) tarafından geliştirilmiş ve Yıldırım vd. (2016) tarafından Türkçe'ye uyarlanmış Nomofobi Ölçeği kullanılmıştır. "Bilgiye Ulaşamama”, "Cihazdan Yoksunluk", "İletişimi Kaybetme" ve "Çevrimiçi Olamama" alt boyutlarından oluşan ölçek, toplam 20 maddeye sahiptir. Orijinali 7'li Liket tipi ölçekten oluşmasına karşın bu çalışmada, katılımcıların cevap vermelerini kolaylaştırmak amaciyla 5'li Likert tipi ölçek tercih edilmiştir. Buna ek olarak her bir öğrencinin dersi derste dinleme ve derse katılım düzeyleri, kendileri tarafından 10 üzerinden derecelendirilmiştir (1: Düşük düzey; 5: Orta düzey, 10: Yüksek düzey). Mevcut literatürün taranmasıyla oluşturulmuş olan demografik bilgi formunda katılımcıların; cinsiyet, yaş, bölüm bilgileri; akıllı telefon kullanım özellikleriyle ilgili olarak telefonun günlük kontrol edilme sıklığı, yanında şarj cihazı taşınma durumu, uyanır uyanmaz telefonun kontrol edilme durumu, yatakta telefonla zaman geçirilme durumu, telefonun gece kapatılma durumuyla ilgili bilgiler; çevrimiçi ortamlarda yer alma durumuyla ilgili olarak ise sosyal medyada sahip olunan hesap sayısl, akıllı telefon 
üzerinden sosyal medyanın günlük kullanım süresi gibi bilgiler yer almaktadir.

\section{Verilerin Toplanması ve Analizi}

Verilerin toplanmasında yüz yüze anket yönteminden faydalanılmıştır. Verilerin analizinde frekans, yüzde, ortalama, standart sapma gibi betimsel istatistikler ile doğrulayıcı faktör analizive yapısal eşitlik modeli kullanılmıştır. İlgili analizlerin gerçekleştirilmesinde SPSS V.21 ve AMOS V.23 programlarından faydalanılmıştır.

\section{Bulgular ve Yorumlar}

Tablo 1 incelendiğinde; katılımcıların \%75,6'sının kadınlardan oluştuğu ve yaş ortalamalarının $21,7( \pm 4,6)$ olduğu görülmektedir. Öğrencilerin \%20,2'si ilk ve acil yardım, \%12,4'ü radyoterapi, \%13,2'si ebelik, \%12,4'ü hemşirelik, $\% 22,1^{\prime} i$ anestezi, \%19,8'i ise fizyoterapi bölümlerinde okumaktadırlar. Katılımcıların akıllı telefonlarını gün içerisinde ortalama 35,8 kez kontrol etmekte, $\% 50,8$ 'i yanlarında sürekli şarj cihazı taşımakta, \%82,2'si uyanır uyanmaz akıllı telefonlarını kontrol etmekte, \%95'i yatağa akıllı telefonla girmekte, $\% 87,2$ 'si geceleri akıllı telefonunu kapatmamakta, \%34,1'i en az dört farklı sosyal medya hesabına sahip olup, ortalaması 3,17 $( \pm 1,6)^{\prime}$ dir. Ayrıca katılımcıların \%13,6'sı günde en az 7 saatini akıllı telefonları üzerinden girdikleri sosyal mecralarda geçirmekte olup, ortalama çevrimiçi kalma süreleri 3,4 $( \pm 1,2)$ saattir. Öğrencilerin dersi derste dinleme düzeylerine atfettikleri genel ortalamanın 7,30 ( $\pm 2,4)$; derse katılım düzeylerine atfettikleri genel ortalamanın ise 6,78 $( \pm 2,4)$ olduğu hesaplanmıştır. Bir diğer ifadeyle öğrencilerin \%73'ü dersi derste dinlediklerini, yaklaşık $\% 68$ 'i ise derse katılım gösterdiklerini belirtmişlerdir. 
Tablo 1. Katılımcılarnn demografik nitelikleri (n: 258)

\begin{tabular}{|c|c|c|c|}
\hline Değişkenler & & $\mathbf{f}$ & $\%$ \\
\hline \multirow{2}{*}{ Cinsiyet } & Kadın & 195 & 75,6 \\
\hline & Erkek & 63 & 24,4 \\
\hline \multirow{3}{*}{ Yaş } & $\leq 20$ & 146 & 56,6 \\
\hline & $\geq 21$ & 112 & 43,4 \\
\hline & Ortalama/S.S. & 21,7 & 4,6 \\
\hline \multirow{6}{*}{ Bölüm } & İlk ve acil yardım & 52 & 20,2 \\
\hline & Radyoterapi & 32 & 12,4 \\
\hline & Ebelik & 34 & 13,2 \\
\hline & Hemşirelik & 32 & 12,4 \\
\hline & Anestezi & 57 & 22,1 \\
\hline & Fizyoterapi & 51 & 19,8 \\
\hline \multirow{5}{*}{ Akıllı telefonu günlük kontrol etme sıklığ } & $1-16 \mathrm{kez}$ & 46 & 17,8 \\
\hline & $17-32 \mathrm{kez}$ & 91 & 35,3 \\
\hline & 3-49 kez & 50 & 19,4 \\
\hline & 50 ve üzeri kez & 71 & 27,5 \\
\hline & Ortalama/S.S. & 35,8 & 23,6 \\
\hline \multirow{2}{*}{ Şarj cihazı taşıma durumu } & Evet & 131 & 50,8 \\
\hline & Hayır & 127 & 49,2 \\
\hline \multirow{2}{*}{ Uyanır uyanmaz akıllı telefon kontrol etme durumu } & Evet & 212 & 82,2 \\
\hline & Hayır & 46 & 17,8 \\
\hline \multirow{2}{*}{ Yatağa akıllı telefonla girme durumu } & Evet & 245 & 95 \\
\hline & Hayır & 13 & 5 \\
\hline \multirow{2}{*}{ Akıllı telefonu gece kapatma durumu } & Evet & 33 & 12,8 \\
\hline & Hayır & 225 & 87,2 \\
\hline \multirow{5}{*}{ Sosyal medyada sahip olunan hesap sayısı } & 1 tane & 39 & 15,1 \\
\hline & 2 tane & 68 & 26,4 \\
\hline & 3 tane & 63 & 24,4 \\
\hline & 4 ve üzeri & 88 & 34,1 \\
\hline & Ortalama/S.S. & 3,17 & 1,6 \\
\hline \multirow{5}{*}{$\begin{array}{l}\text { Akıllı telefon üzerinden sosyal medyanın günlük kulla- } \\
\text { nım süresi }\end{array}$} & 1 saatten az & 36 & 14 \\
\hline & $1-3$ saat & 126 & 48,8 \\
\hline & $4-6$ saat & 61 & 23,6 \\
\hline & 7 saat ve üzeri & 35 & 13,6 \\
\hline & Ortalama/S.S. & 3,4 & 1,2 \\
\hline Dersi derste dinleme düzeyi & Ortalama/S.S. & 7,30 & 2,4 \\
\hline Derse katılım düzeyi & Ortalama/S.S. & 6,78 & 2,4 \\
\hline
\end{tabular}

Araştırma kapsamında kullanılan Nomofobi ölçeğinden elde edilen betimsel istatistikler (ortalama ve standart sapma, basıklık ve çarpıklık) Tablo 2 'de sunulmaktadır. Tablo 2' de yer alan bulgular incelendiğinde; öğrencilerin nomofobi düzeylerinin, ortalamanın üzerinde çıktı̆̆ $(\bar{x}: 3,20, \pm: 0,81)$ görülmektedir. Nomofobi ölçeği alt boyutlarından Çevrimiçi Olamama (x:2,46, \pm : 
1,04) faktörü dışındaki diğer alt boyutların ise, genel ölçek ortalamasının üs-

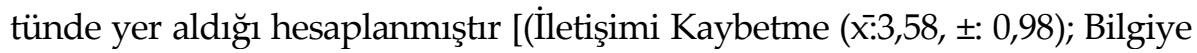
Ulaşamama (x:3,55, $\pm:$ 0,88); Cihazdan Yoksunluk (x:3,25, $\pm: 0,99)]$. Ölçeğin ortalama ve standart sapma değerlerine ek olarak, verilerin normal dağılıp dağılmadıklarını teyit etmek amacıyla Kolmogorov-Smirnov testi yapılmış ve normal dağılım değerinin $\mathrm{p}<0,05$ değerinden düşük çıtığı görülmüştür. $\mathrm{Bu}$ nedenle verilerin basıklık ve çarpıklık değerlerine bakılmıştır. Tabachnick ve Fidell (2007), bir veri setinin normal dağılıma uygun olması için basıklık ve çarpıklık değerlerinin mutlak değer içerisinde $\pm 1,96$ arasında yer alması gerektiğini ifade etmektedirler. Bu bağlamda Nomofobi Ölçeği için basıklık değerinin $|-1,35|$ ile $|0,31|$; çarpıklık değerinin ise $|-0,96|$ ile $|0,96|$ bandında yer aldığ 1 ve 0,05 anlamlılık düzeyinde verilerin normal dağılıma uygun olduğu belirtilebilir. Ölçeğin Cronbach Alfa iç tutarlık katsayıları incelendiğinde; Bilgiye Ulaşamama boyutunun 0,789, Cihazdan Yoksunluk boyutunun 0,823, İletişimi Kaybetme boyutunun 0,913, Çevrimiçi Olamama boyutunun 0,882 , genel Nomofobi Ölçeği güvenirlik katsayısının ise 0,934 olduğu hesaplanmıştır. Dolayısıyla Nomofobi Ölçeği'nin yüksek bir iç güvenirlik katsayısına sahip olduğu ifade edilebilir.

Tablo 2. Nomofobi ölçeğine ilişkin betimsel göstergeler

\begin{tabular}{|c|c|c|c|c|c|c|}
\hline Boyut & Kodlar & Ölçek İfadeleri & 丞 & 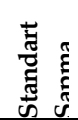 & $\frac{y}{\vec{z}}$ & صू. \\
\hline \multirow{4}{*}{ 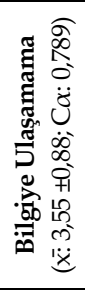 } & Nomo-1 & $\begin{array}{l}\text { Akıllı telefonumdan sürekli olarak bilgiye erişemediğimde ken- } \\
\text { dimi rahatsız hissederim }\end{array}$ & 3,62 & 1,02 & $-0,75$ & $-0,01$ \\
\hline & Nomo-2 & $\begin{array}{l}\text { Akıllı telefonumdan istediğim her an bilgiye bakamadığımda } \\
\text { canım sıkılır }\end{array}$ & 3,60 & 1,08 & $-0,69$ & $-0,43$ \\
\hline & Nomo-3 & $\begin{array}{l}\text { Haberlere (örneğin neler olup bittiğine, hava durumuna ve diğer } \\
\text { haberlere) akıllı telefonumdan ulaşamamak beni huzursuz yapar }\end{array}$ & 3,39 & 1,23 & $-0,46$ & $-0,96$ \\
\hline & Nomo-4 & $\begin{array}{l}\text { Akıllı telefonumu ve telefonumun özelliklerini istediğim her an } \\
\text { kullanamadığımda rahatsız olurum }\end{array}$ & 3,58 & 1,14 & $-0,56$ & $-0,63$ \\
\hline \multirow{5}{*}{ 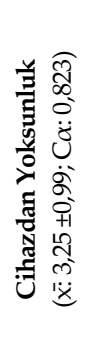 } & Nomo-5 & Akıllı telefonumun şarjının bitmesinden korkarım & 3,78 & 1,26 & $-0,87$ & $-0,39$ \\
\hline & Nomo-6 & $\begin{array}{l}\text { Kontörüm (TL kredim) bittiğinde veya aylık kota sınırımı aştı- } \\
\text { ğımda paniğe kapılırım }\end{array}$ & 3,10 & 1,38 & $-0,14$ & $-1,35$ \\
\hline & Nomo-7 & $\begin{array}{l}\text { Telefonum çekmediğinde veya kablosuz internet bağlantısına } \\
\text { erişemediğimde sürekli olarak sinyal olup olmadığını veya kab- } \\
\text { losuz erişim bağlantısı bulup bulamayacağımı kontrol ederim }\end{array}$ & 3,41 & 1,28 & $-0,40$ & $-1,05$ \\
\hline & Nomo-8 & $\begin{array}{l}\text { Akıllı telefonumu kullanamadığımda, bir yerlerde mahsur kala- } \\
\text { cağımdan korkarım. }\end{array}$ & 2,60 & 1,38 & 0,40 & $-1,14$ \\
\hline & Nomo-9 & $\begin{array}{l}\text { Akıllı telefonuma bir süre bakamadıysam, bakmak için güçlü bir } \\
\text { istek hissederim }\end{array}$ & 3,34 & 1,20 & $-0,37$ & $-0,94$ \\
\hline
\end{tabular}




\begin{tabular}{|c|c|c|c|c|c|c|}
\hline \multirow{6}{*}{ 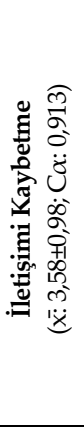 } & Nomo-10 & $\begin{array}{l}\text { Eğer akıllı telefonum yanımda değilse, ailemle ve/veya arkadaş- } \\
\text { larımla hemen iletiştim kuramayacağım için kaygı duyarım }\end{array}$ & 3,53 & 1,21 & $-0,73$ & $-0,47$ \\
\hline & Nomo-11 & $\begin{array}{l}\text { Eğer akıllı telefonum yanımda değilse, ailem ve/veya arkadaşla- } \\
\text { rım bana ulaşamayacakları için endişelenirim }\end{array}$ & 3,75 & 1,11 & $-0,96$ & 0,31 \\
\hline & Nomo-12 & $\begin{array}{l}\text { Eğer akıllı telefonum yanımda değilse, gelen aramaları ve me- } \\
\text { sajları alamayacağım için kendimi huzursuz hissederim }\end{array}$ & 3,58 & 1,16 & $-0,62$ & $-0,56$ \\
\hline & Nomo-13 & $\begin{array}{l}\text { Eğer akıllı telefonum yanımda değilse, ailemle ve/veya arkadaş- } \\
\text { larımla iletişim halinde olamadığım için endişelenirim }\end{array}$ & 3,66 & 1,14 & $-0,82$ & $-0,19$ \\
\hline & Nomo-14 & $\begin{array}{l}\text { Eğer akıllı telefonum yanımda değilse, birinin bana ulaşmaya } \\
\text { çalsşıp çalışmadı̆ı̆ı bilemediğim için gerilirim }\end{array}$ & 3,44 & 1,23 & $-0,53$ & $-0,79$ \\
\hline & Nomo-15 & $\begin{array}{l}\text { Eğer akıllı telefonum yanımda değilse, ailem ve arkadaşlarımla } \\
\text { olan bağlantım kesileceği için kendimi huzursuz hissederim }\end{array}$ & 3,50 & 1,19 & $-0,71$ & $-0,54$ \\
\hline \multirow{5}{*}{ 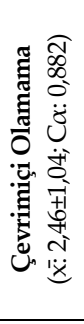 } & Nomo-16 & Online (çevrimiçi) kimliğinden kopacağım için gergin olurum & 2,09 & 1,12 & 0,96 & 0,11 \\
\hline & Nomo-17 & $\begin{array}{l}\text { Sosyal medya ve diğer çevrimiçi ağlarda güncel kalamadığım } \\
\text { için rahatsızlık duyarım }\end{array}$ & 2,39 & 1,30 & 0,67 & $-0,70$ \\
\hline & Nomo-18 & $\begin{array}{l}\text { Bağlantılarımdan ve çevrimiçi ağlardan gelen güncelleme bildi- } \\
\text { rimlerini takip edemediğim için kendimi tuhaf hissederim }\end{array}$ & 2,38 & 1,20 & 0,69 & $-0,53$ \\
\hline & Nomo-19 & $\begin{array}{l}\text { Elektronik postalarımı kontrol edemediğim için kendimi huzur- } \\
\text { suz hissederim }\end{array}$ & 2,48 & 1,29 & 0,51 & $-0,94$ \\
\hline & Nomo-20 & $\begin{array}{l}\text { Akıllı telefonum yanımda olmadığında ne yapacağımı bileme- } \\
\text { mek beni garip hissettirir }\end{array}$ & 2,96 & 1,36 & 0,04 & $-1,31$ \\
\hline \multicolumn{3}{|c|}{ Genel Nomofobi Ölçeği $(C \alpha: 0,934)$} & 3,20 & 0,81 & $-0,30$ & $-0,04$ \\
\hline
\end{tabular}

\section{Öğrencilerin nomofobi algılarını ölçmek amacıyla faydalanılan Nomofobi} Ölçeği'ne ilişkin başlangıç ölçüm modeli Şekil 2' de sunulmaktadır. Tablo 3' de yer verilen DFA sonuçları, Şekil 2'de önerilen ölçüm modelinin araştırma verilerine uyup uymadığı hususunda bilgiler vermektedir.

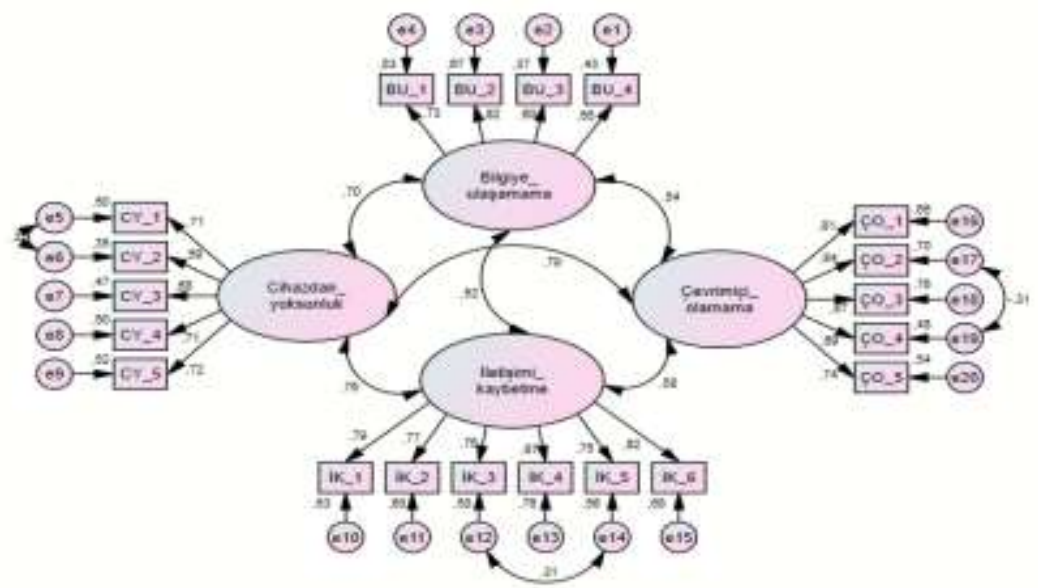

$X^{2} / d f:$ 1,823; NFI: 0,908; IFI: 0,956; TLI: 0,948; CFI: 0,956; RMSEA: 0,057

Şekil 2. katılımcıların nomofobi algıların tanımlayan ölçüm modeli ve uyum değerleri 
Şekil 2 incelendiğinde Bilgiye Ulaşamama gizil değişkenini en çok açıklayan gözlem değişkeninin BU_2; Cihazdan Yoksunluk gizil değişkenini en çok açılayan gözlem değişkeninin CY_5; İletişimi Kaybetme gizil değişkenini en çok açıklayan gözlem değişkeninin İK_4; Çevrimiçi Olamama gizil değişkenini en çok açıklayan gözlem değişkenininse ÇO_3 olduğu görülmektedir. Buna ek olarak modelin uyum iyiliği değerlerini daha da iyileştirmek için, program tarafından önerilen üç adet modifikasyonun yapılması sonucunda, uyum iyiliği değerlerinin kabul edilebilir düzeye eriştiği tespit edilmiştir (X²/df: 1,823; NFI: 0,908; IFI: 0,956; TLI: 0,948; CFI: 0,956; RMSEA: 0,057).

Tablo 3. Araştırma modeline ait ölçüm modelinin parametre değerleri

\begin{tabular}{ccllll}
\hline & & & SRA & t & P \\
\hline BU_1 & $\leftarrow$ & Bilgiye Ulaşamama & 0,730 & & \\
\hline BU_2 & $\leftarrow$ & Bilgiye Ulaşamama & 0,820 & 11,853 & $<0,001$ \\
\hline BU_3 & $\leftarrow$ & Bilgiye Ulaşamama & 0,604 & 8,627 & $<0,001$ \\
\hline BU_4 & $\leftarrow$ & Bilgiye Ulaşamama & 0,654 & 9,06 & $<0,001$ \\
\hline CY_1 & $\leftarrow$ & Cihazdan Yoksunluk & 0,707 & & \\
\hline CY_2 & $\leftarrow$ & Cihazdan Yoksunluk & 0,588 & 10,4 & $<0,001$ \\
\hline CY_3 & $\leftarrow$ & Cihazdan Yoksunluk & 0,682 & 10,184 & $<0,001$ \\
\hline CY_4 & $\leftarrow$ & Cihazdan Yoksunluk & 0,706 & 10,254 & $<0,001$ \\
\hline CY_5 & $\leftarrow$ & Cihazdan Yoksunluk & 0,719 & 10,578 & $<0,001$ \\
\hline IK_1 & $\leftarrow$ & İletişimi Kaybetme & 0,793 & & $<0,001$ \\
\hline İ_2 & $\leftarrow$ & İletişimi Kaybetme & 0,775 & 13,567 & $<0,001$ \\
\hline İK3 & $\leftarrow$ & İletişimi Kaybetme & 0,762 & 13,097 & $<0,001$ \\
\hline İK_4 & $\leftarrow$ & İletişimi Kaybetme & 0,873 & 15,661 & $<0,001$ \\
\hline İK_5 & $\leftarrow$ & İletişimi Kaybetme & 0,746 & 12,709 & $<0,001$ \\
\hline İK_6 & $\leftarrow$ & İletişimi Kaybetme & 0,824 & 14,609 & \\
\hline ÇO_1 & $\leftarrow$ & Çevrimiçi Olamama & 0,809 & & $<0,001$ \\
\hline ÇO_2 & $\leftarrow$ & Çevrimiçi Olamama & 0,839 & 15,414 & $<0,001$ \\
\hline ÇO_3 & $\leftarrow$ & Çevrimiçi Olamama & 0,873 & 16,393 & $<0,001$ \\
\hline ÇO_4 & $\leftarrow$ & Çevrimiçi Olamama & 0,692 & 11,788 & $<0,001$ \\
\hline ÇO_5 & $\leftarrow$ & Çevrimiçi Olamama & 0,738 & 12,869 & \\
\hline & & & &
\end{tabular}

Ölçüm modelinin parametre değerlerini içeren Tablo 3 incelendiğinde; SRA değerlerinin 0,588 ile 0,873 arasında değiştiği ve dolayısıyla 0,50'nin altında herhangi bir SRA değerinin olmadığı görülmektedir. Ayrıca gizil ve gözlem değişkenleri arasındaki tüm yolların anlamlı olması dolayısıyla modelden herhangi bir değişkenin çıkartılması söz konusu olmamıştır. 


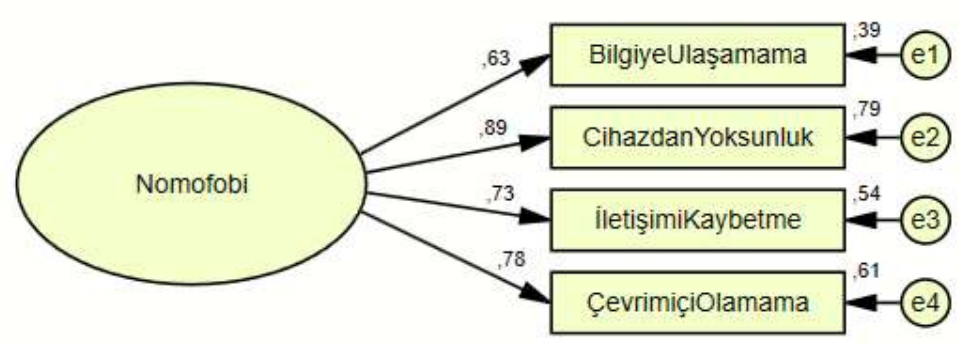

$X^{2} / d f:$ 1,134; NFI: 0,999; IFI: 1,000; TLI: 1,000; CFI: 0,998; RMSEA: 0,011 Şekil 3. Katılımcılarn nomofobi algıların tanımlayan ölçüm modeli ve uyum değerleri

Şekil 3'de yer verilen ölçüm modelinde Bilgiye Ulaşamama, Cihazdan Yoksunluk, İletişimi Kaybetme ve Çevrimiçi Olamama boyutlarından meydana gelen dörtlü yapının, nomofobi gizil değişkenini açıklayıp açıklamadığı ele alınmıştır. Tablo 4'de sunulan modele ait değerler göz önünde bulundurulduğunda, her bir boyutun 0,50'den daha büyük faktör yüklerine sahip olması dolayısıyla tüm boyutların nomofobi örtük değişkenini açıklamada anlamlı olduğu ve önerilen ölçüm modelinin araştırma verisine uygunluk gösterdiği görülmektedir (X²/df: 1,134; NFI: 0,999; IFI: 1,000; TLI: 1,000; CFI: 0,998; RMSEA: 0,011).

Tablo 4. Ölçüm modelinin regresyon ağırlıklarn

\begin{tabular}{llllll}
\hline & & & SRA & t & P \\
\hline Bilgiye Ulaşamama & $\leftarrow$ & Nomofobi & 0,626 & & \\
\hline Cihazdan Yoksunluk & $\leftarrow$ & Nomofobi & 0,890 & 10,507 & $<0,001$ \\
\hline İletişimi Kaybetme & $\leftarrow$ & Nomofobi & 0,733 & 9,497 & $<0,001$ \\
\hline Çevrimiçi Olamama & $\leftarrow$ & Nomofobi & 0,778 & 9,864 & $<0,001$ \\
\hline
\end{tabular}

Nomofobi gizil değişkenini etkileyen değişkenlerin belirlenmesi amacıyla Şekil 4' de yer alan model oluşturulmuştur. Burada katılımcıların on farklı demografik ve diğer özelliğine (cinsiyet, yaş, bölüm, akıllı telefonun günlük kontrol edilme sayısı, şarj cihazı taşıma durumu, uyanır uyanmaz akıllı telefon kontrol etme durumu, yatmadan önce akıllı telefonla zaman geçirme durumu, akıllı telefonu gece kapatma durumu, sosyal mecrada sahip olunan hesap sayısı ve akıllı telefon üzerinden sosyal mecrada harcanan günlük süre) yer verilmiş olup, Tablo 5 'deki sonuçlardan başlangıç yapısal modelde cinsiyet (t: -0,980; p: 0,327), yaş (t: 0,243; p: 0,808), bölüm (t: -0,772; p: 0,440), 
yatmadan önce akull telefonla zaman geçirme durumu (t: -1,787; p: 0,074), akall telefonu gece kapatma durumu (t: 1,509; p: 0,131) ve sosyal medyada sahip olunan hesap sayısı (t: -1,494; p: 0,135) değişkenleri ile nomofobi gizil değişkeni arasındaki yollara ait t-değerlerinin 0,05 düzeyinde anlamlılık arz etmediği saptanmıştır. Dolayısıyla $\mathrm{H}_{1}, \mathrm{H}_{2}, \mathrm{H}_{3}, \mathrm{H}_{7}, \mathrm{H}_{8}$ ve $\mathrm{H}_{9}$ hipotezlerinin desteklenmediği ifade edilebilir. Bir diğer taraftan katılımcıların; akıllı telefonu günlük kontrol etme sayıları, şarj cihazı taşıma durumları, uyanır uyanmaz akıllı telefonların kontrol etme durumlarıve akıllı telefon üzerinden sosyal mecrada harcadıkları günlük süre değişkenleri nomofobi düzeylerini anlamlı şekilde etkilemektedir $(\mathrm{p}<0,05)$. Ancak, önerilen başlangıç yapısal modelin uyum iyiliği değerleri modelin kabul edilebilir sınırlar içinde olmadığını göstermektedir (X²/df: 3,811; NFI: 0,580; IFI: 0,652; TLI: 0,591; CFI: 0,645; RMSEA: $0,105)$.

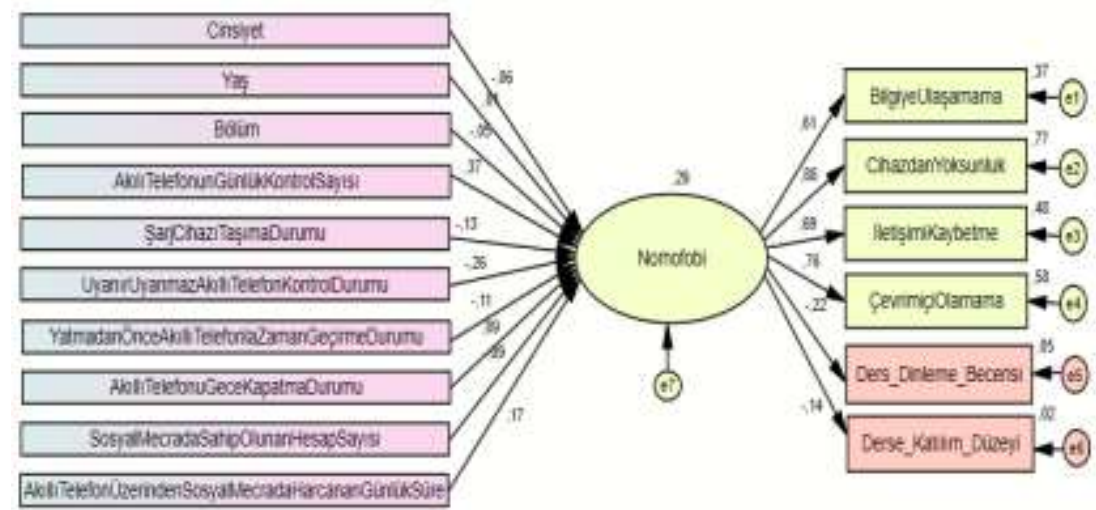

$X^{2} / d f: 3,811 ;$ NFI: 0,580; IFI: 0,652; TLI: 0,591; CFI: 0,645; RMSEA: 0,105

Şekil 4. Katılımcılarnn nomofobi düzeylerini tahminleyen başlangıç yapısal model ve uyum değerleri

Tablo 5. Katılımcıların nomofobi algıların tahmin eden başlangıç yapısal modelin regresyon ă̆ırliklarn

\begin{tabular}{llllll} 
& & & SRA & t & P \\
\hline Nomofobi & $\leftarrow$ & Cinsiyet & $-0,061$ & $-0,980$ & 0,327 \\
\hline Nomofobi & $\leftarrow$ & Yaş & 0,015 & 0,243 & 0,808 \\
\hline Nomofobi & $\leftarrow$ & Bölüm & $-0,046$ & $-0,772$ & 0,440 \\
\hline Nomofobi & $\leftarrow$ & Akıllı Telefonun Günlük Kontrol Sayısı & 0,372 & 5,526 & $\mathrm{p}<0,001$ \\
\hline Nomofobi & $\leftarrow$ & Şarj Cihazı Taşıma Durumu & $-0,128$ & $-2,051$ & 0,040 \\
\hline Nomofobi & $\leftarrow$ & Uyanır Uyanmaz Akıllı Telefon Kontrol Durumu & $-0,259$ & $-3,869$ & $\mathrm{p}<0,001$ \\
\hline \multirow{2}{*}{ Nomofobi } & $\leftarrow$ & $\begin{array}{l}\text { Yatmadan Önce Akıllı Telefonla Zaman } \\
\text { Geçirme Durumu }\end{array}$ & $-0,111$ & $-1,787$ & \multirow{2}{*}{0,074} \\
\hline
\end{tabular}




\begin{tabular}{llllll}
\hline Nomofobi & $\leftarrow$ & Akıllı Telefonu Gece Kapatma Durumu & 0,091 & 1,509 & 0,131 \\
\hline Nomofobi & $\leftarrow$ & Sosyal Mecrada Sahip Olunan Hesap Sayısı & $-0,094$ & $-1,494$ & 0,135 \\
\hline Nomofobi & $\leftarrow$ & $\begin{array}{l}\text { Akıllı Telefon Üzerinden Sosyal Mecrada } \\
\text { Harcanan Günlük Süre }\end{array}$ & 0,172 & 2,450 & 0,014 \\
\hline $\begin{array}{l}\text { Cihazdan } \\
\text { Yoksunluk }\end{array}$ & $\leftarrow$ & Nomofobi & 0,877 & 14,251 & $\mathrm{p}<0,001$ \\
\hline $\begin{array}{l}\text { lletişimi } \\
\text { Kaybetme }\end{array}$ & $\leftarrow$ & Nomofobi & 0,690 & 11,618 & $\mathrm{p}<0,001$ \\
\hline $\begin{array}{l}\text { Çevrimiçi } \\
\text { Olamama }\end{array}$ & $\leftarrow$ & Nomofobi & 0,761 & & \\
\hline $\begin{array}{l}\text { Bilgiye } \\
\text { Ulaşamama }\end{array}$ & $\leftarrow$ & Nomofobi & 0,612 & 10,148 & $\mathrm{p}<0,001$ \\
\hline $\begin{array}{l}\text { Ders } \\
\text { Dinleme Becerisi }\end{array}$ & $\leftarrow$ & Nomofobi & $-0,219$ & $-3,535$ & $\mathrm{p}<0,001$ \\
\hline $\begin{array}{l}\text { Derse } \\
\text { Katıllım Düzeyi }\end{array}$ & $\leftarrow$ & Nomofobi & $-0,141$ & $-2,265$ & 0,023 \\
\hline
\end{tabular}

Öğrencilerin nomofobi düzeylerinietkileyen faktörleri tanımlamak amacıyla önerilen başlangıç yapısal modelin bir bütün olarak uyum iyiliği değerleri kabul edilebilir düzeyde olmadığından başlangıç modele göre daha iyi bir uyum değerleri elde edebilmek için modeldeki anlamsız yollar analizden çıkarılmıştır. Bu doğrultuda; cinsiyet, yaş, bölüm, yatmadan önce akıllı telefonla zaman geçirme durumu, akıllı telefonu gece kapatma durumu ile sosyal mecrada sahip olunan hesap sayısı değişkenlerinin öğrencilerin genel nomofobi düzeyleri üzerinde anlamlı bir etkiye sahip olmaması dolayısıyla analizden çıkarılmış ve süreç yeniden başlatılmıştır. Yeni yapısal model Şekil 5 'de yer almaktadır.

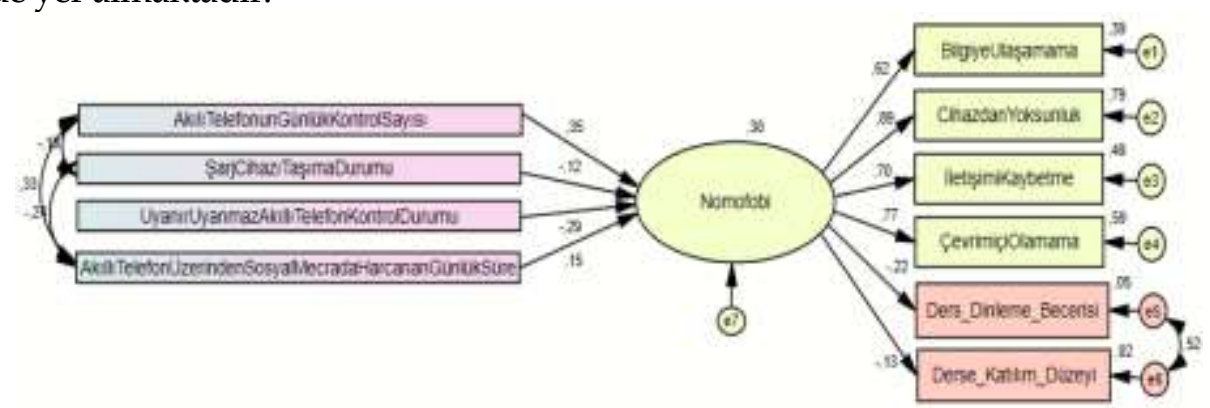

$X^{2} /$ df: 2,097; NFI: 0,911; IFI: 0,952; TLI: 0,928; CFI: 0,951; RMSEA: 0,065

Şekil 5. Katılımcılarnn nomofobi algıların tahmin eden tahmin gözden geçirilmiş

yapısal model ve uyum değerleri 
Şekil 5'deki revize edilmiş modele ait parametre tahmin değerlerinin yer aldığ 1 Tablo 6 incelendiğinde; akıll telefonun günlük kontrol edilme sayısı (t: 5,431; $\mathrm{p}<0,001)$, şarj cihazı taşıma durumu (t: -2,077; $\mathrm{p}<0,05)$, uyanır uyanmaz akıll telefonun kontrol edilme durumu (t: $-4,780 ; \mathrm{p}<0,001)$ ile akıll telefon üzerinden sosyal mecrada harcanan günlük süre (t: 2,393; $\mathrm{p}<0,05)$ değişkenlerinin öğrencilerin nomofobi düzeyleri üzerinde anlamlı etkisinin olduğu ortaya konulmultur. Standardize Regresyon Ağırlıkları (SRA) göz önünde bulundurulduğunda öğrencilerin nomofobi düzeyleri üzerinde en büyük etkinin akıllı telefonun günlük kontrol edilme sayısı ( $(\beta: 0,345)$ olduğu ve bunu akıllı telefon üzerinden sosyal mecrada harcanan günlük sürenin ( $\beta$ : $0,151)$ takip ettiği görülmektedir. Buradan hareketle öğrencilerin gün içerisinde kendilerine gelen çeşitli bildirimleri kontrol etmek amaciyla akıllı telefonlarını kontrol etme sıklıkları ile akıllı telefonları üzerinden sosyal ağlara bağlanarak geçirdikleri süre ne kadar artarsa, nomofobi düzeylerinin de bu doğrultuda artış göstereceği ifade edilebilir. Çalışma hipotezleri değerlendirildiğinde $\mathrm{H}_{4}$ ve $\mathrm{H}_{10}$ hipotezlerinin desteklendiği belirtilebilir. Öte yandan; uyanir uyanmaz akıllı telefonun kontrol edilme durumu $(\beta:-0,294)$ ile yanında sürekli şarj cihazı bulundurma durumu $(\beta$ : $-0,125)$ değişkenlerinin, öğrencilerin nomofobi düzeyleri üzerinde negatif yönde anlamlı bir etkisi olduğu saptanmıştır. Araştırma kapsamında ileri sürülen hipotezler göz önünde bulundurulduğunda $\mathrm{H}_{5}$ ve $\mathrm{H}_{6}$ hipotezlerinin de desteklendiği ortaya konulmuştur. Modelin uyum iyiliği parametreleri incelendiğinde başlangıç modele kıyasla uyum iyiliği indekslerinin belirgin şelilde iyileştiği görülmüş (X²/df: 2,097; NFI: 0,911; IFI: 0,952; TLI: 0,928; CFI: 0,951; RMSEA: 0,065) ve bu çalışmanın nihai modelinin Şekil 4'deki gibi olduğu kabul edilmiştir. Özetle öğrencilerin nomofobi düzeylerinin \%30'unun; akıllı telefonun günlük kontrol edilme sıklığı, yanında şarj cihazı bulundurma durumu, uyanır uyanmaz akıllı telefonu kontrol etme durumu ve akıllı telefon üzerinden sosyal mecrada harcanan günlük süre değişkenleri tarafından yordadığı tespit edilmiştir.

Bir diğer taraftan, öğrencilerin dersi derste dinleme $(\beta:-0,216)$ ve derse katılım düzeyleri $(\beta:-0,127)$ üzerinde nomofobinin negatif ve anlamlı bir etkisi tespit edilmiştir. Dolayısıyla $\mathrm{H}_{15}$ ve $\mathrm{H}_{16}$ hipotezleri desteklenmiştir. Öğrencilerin dersi derste dinleme performanslarının yaklaşık \%22'sinin, derse katılım performanslarının ise yaklaşık \%13'ünün nomofobi düzeyleri tarafından açılandığı belirlenmiştir. Ayrıca nomofobi gizil değişkeni ve onun alt boyutlarını teşkil eden gözlem değişkenleri arasındaki tüm yolların da pozitif ve 
anlamlı olduğu belirlenmiştir (Cihazdan Yoksunluk $\beta$ : 0,891; Çevrimiçi Olamamaß: 0,76; İletişimi Kaybetmeß: 0,700; Bilgiye Ulaşamamaß: 0,622). Bu bağlamda H11, $\mathrm{H}_{12}, \mathrm{H}_{13}$ ve $\mathrm{H}_{14}$ hipotezlerinin desteklendiği ifade edilebilir.

Tablo 6. Katılımcıların nomofobi algıların tahmin eden gözden geçirilmiş yapısal modelin regresyon ă̆ırlıkları

\begin{tabular}{lllll}
\hline & & SRA & $\mathbf{t}$ & P \\
\hline Nomofobi & $\leftarrow$ Akıllı Telefonun Günlük Kontrol Sayısı & 0,345 & 5,431 & $\mathrm{p}<0,001$ \\
\hline Nomofobi & $\leftarrow$ Şarj Cihazı Taşıma Durumu & $-0,125$ & $-2,077$ & 0,038 \\
\hline Nomofobi & $\leftarrow \begin{array}{l}\text { Uyanır Uyanmaz Akıllı Telefon } \\
\text { Kontrol Durumu }\end{array}$ & $-0,294$ & $-4,780$ & $\mathrm{p}<0,001$ \\
\hline Nomofobi & $\leftarrow \begin{array}{l}\text { Akıllı Telefon Üzerinden Sosyal Mecrada } \\
\text { Harcanan Günlük Süre }\end{array}$ & 0,151 & 2,393 & 0,017 \\
\hline Cihazdan Yoksunluk & $\leftarrow$ Nomofobi & 0,891 & 14,168 & $\mathrm{p}<0,001$ \\
\hline $\begin{array}{l}\text { İetişimi } \\
\text { Kaybetme }\end{array}$ & $\leftarrow$ Nomofobi & 0,700 & 11,614 & $\mathrm{p}<0,001$ \\
\hline Çevrimiçi Olamama & $\leftarrow$ Nomofobi & 0,769 & & \\
\hline $\begin{array}{l}\text { Bilgiye } \\
\text { Ulaşamama }\end{array}$ & $\leftarrow$ Nomofobi & 0,622 & 10,116 & $\mathrm{p}<0,001$ \\
\hline Ders Dinleme Becerisi & $\leftarrow$ Nomofobi & $-0,216$ & $-3,400$ & $\mathrm{p}<0,001$ \\
\hline Derse Katıllım Düzeyi & $\leftarrow$ Nomofobi & $-0,127$ & $-1,994$ & 0,046 \\
\hline
\end{tabular}

\section{Tartışma ve Sonuç}

Üniversite öğrencilerinin nomofobi düzeylerini etkileyen faktörleri incelemek ve ders performansları üzerinde nomofobinin etkisi saptamak amaciyla ele alınan çalışma, sağlıkla ilgili farklı bölümlerde okuyan 258 öğrencinin katılımıyla gerçekleştirilmiştir. Öğrencilerin nomofobi düzeylerinin ortalamanın üzerinde çıktığı sonucuna varılmıştır. Bir diğer ifadeyle öğrencilerin nomofobik eğilime sahip oldukları sonucuna varılmıştır. Adnan ve Gezgin (2016); Burucuoğlu (2017); Gezgin vd. (2017) tarafından yapılan çalışmalarda da öğrencilerin ortalamanın üzerinde nomofobi düzeyine sahip oldukları raporlanmıştır. Benzer şekilde Hakkari (2018)'nin çalışmasında öğrencilerin \%51'inin; Erdem vd. (2016)'nin çalışmasında ise \%55'inin nomofobik düzeyde olduğu tespit edilmiştir. Uluslararası literatür incelendiğinde 473 tıp fakültesi öğrencisiyle Hindistan'da yapılan bir çalışmada (Sethia vd., 2018) öğrencilerin \%6,1'inin; 418 tıp öğrencisiyle yürütülen bir çalışmada (Harish ve Bharath, 2018) \%13,5'inin; 145 tıp fakültesi öğrencisiyle gerçekleştirilen bir çalışmada (Farooqui vd.,2017) \%22,1'inin; Davie ve Hilber (2017)'in çalışmasında ise \%3'e yakınının ciddi düzeyde nomofobik olduğu saptanmıştır. 
Bu çalışmada cinsiyet değişkeninin, öğrencilerin nomofobi düzeyleri üzerinde anlamlı etkisinin olmadığı sonucuna varılmıştır. Ak ve Yıldırım (2018) ile Yıldız D. (2018b)'nin çalışmalarında, değişkenler arasında anlamlı bir ilişkinin olmadığı rapor edilmiştir. Adnan ve Gezgin (2016), Erdem vd. (2016), Gezgin ve Parlak (2018), Kocabaş ve Korucu (2018), Öz ve Tortop (2018), Yorulmaz vd. (2018), Uysal vd. (2016) ile Yıldırım (2017)'ın çalışmalarında da, değişkenler arasında anlamlı bir farklılık olmadığı belirlenmiştir. Yıldırım vd. (2016)'nin çalışmasında ise nomofobi üzerinde cinsiyetin anlamlı etkisi görülmüştür.

Çalışma kapsamında elde edilen bir diğer benzer sonuç; öğrencilerin nomofobi düzeyleri üzerinde yaş değişkeninin anlamlı bir etkiye sahip olmadığıdır. Bu bağlamda çalışma bulguları Yildirim vd. (2016) ile Ak ve Yıldırım (2018)'nkiyle paralellik gösterirken; Yıldız D. (2018b), Erdem vd. (2017) ve Gezgin ve Parlak (2018)'ın çalışmalarıyla örtüşmemektedir. Yıldız D. (2018b)'nin çalışmasında anlamlı ilişkinin yönü pozitifken; Erdem vd. (2017) ile Gezgin ve Parlak (2018)'ın çalışmalarında ise negatiftir. Çalışma bulguları ile paralel olarak Adnan ve Gezgin (2016), Çelik ve Atilla (2018) ile Öz ve Tortop (2018)'un çalışmaları da, yaş ile nomofobi arasında anlamlı bir farklılığın olmadığını ortaya koymaktadır.

Öğrencilerin nomofobi düzeyleri üzerinde, yanlarında şarj cihazı taşıma durumlarının anlamlı etkisinin görüldüğü bu çalışmaya paralel olarak Çelik ve Atilla (2018), Hoşgör vd. (2017a), Sırakaya (2018) ve Yoğurtçu (2018)'nun çalışmaları, yanlarında şarj cihazı taşıyan katılımcılar lehine anlamlı farklılıkların olduğunu ortaya koymaktadır. Gutiérrez-Puertas (2019) tarafından 258 İspanyol ve Portekiz hemşirelik öğrencisiyle yürütülen bir araştırmada; Portekizli öğrencilerin nomofobi düzeyleri daha yüksek hesaplanmıştır. Eğer akıllı telefonlarının şarjları biterse, Portekizli öğrencilerin daha fazla gerginlik hissettikleri ortaya konulmuştur. Yine benzer şekilde Portekizli öğrencilerin, aile ve arkadaşları ile sürekli iletişim halinde olmaya daha fazla ihtiyaç duydukları sonucuna varılmıştır.

Çalışma kapsamında öğrencilerin nomofobi düzeyleri üzerinde, akıllı telefonlarını geceleri kapatma durumu değişkeninin anlamsız etkisi tespit edilmiştir. Benzaer şekilde Hoşgör vd. (2017a)'nin çalı̧̧masında da değişkenler arasında anlamsız bir farklılık saptanmasına karşın, Sırakaya (2018)'nın çalışmasındaysa; değişkenler arasında, geceleri mobil telefonlarını kapatmayan katılımcllar lehine anlamlı bir farklılık bulunmuştur. 
Akıllı telefonun günlük kontrol edilme sıklı̆̆ının, öğrencilerin nomofobi düzeyleri üzerinde pozitif ve anlamlı bir etkiye sahip olduğunun belirlendiği bu çalışmaya paralel olarak Çelik ve Atilla (2018), Durak ve Seferoğlu (2018), Gezgin vd. (2017), Gezgin vd. (2018b), Hakkari (2018), Sırakaya (2018), Gezgin (2017), Yoğurtçu (2018) ve Büyükçolpan (2019) değişkenler arasında anlamlı bir farklılık (günde daha çok kez kontrol edenler lehine) olduğu sonucuna varmıştır. Prasad vd. (2017)'nin çalışmasında ise \%24'ü nomofobik kategoride yer aldığı belirlenen öğrencilerin yaklaşık \%25'inin klinik stajlarında ve ders esnasında sık sık akıllı telefonlarını kontrol ettiklerisaptanmıştır. Bunun aksine Yıldız D. (2018b); değişkenler arasında anlamlı fakat negatif bir ilişki bulduğunu rapor etmiştir.

Uyanır uyanmaz akıllı telefon kontrol etme durumu değişkeninin, öğrencilerin nomofobi düzeyleri üzerinde negatif ve anlamlı bir etki gösterdiğinin belirlendiği bu çalışmaya benzer olarak; Çelik ve Atilla (2018), Hoşgör vd. (2017a), Sırakaya (2018) ve Yoğurtçu (2018) tarafından gerçekleştirilmiş olan çalışmalarda da ilgili değişkenler arasında anlamlı farklılıkların (uyanır uyanmaz kontrol ettiğini belirtenler lehine) keşfedildiği bildirilmiştir.

Çalışma kapsamında öğrencilerin yatağa akıllı telefonla girme ve onunla vakit geçirme durumu değişkeninin, nomofobi düzeyleri üzerinde etkisi olmadığ1 tespit edilmiştir. Buna karşın; Hoşgör vd. (2017a) ile Yoğurtçu (2018)'nun çalışma bulguları değişkenler arasında, uyumadan önce akıllı telefonla vakit geçirdiğini belirten öğrenciler lehine anlamlı bir farklılık görüldügünü ortaya koymaktadır.

Çalışma kapsamında, öğrencilerin nomofobi düzeyleri üzerindeakıllı telefonları vasıtasıyla sosyal medyanın günlük kullanım süresi değişkenlerinin pozitif ve anlamlı etkisi teyit edilmiştir. Yıldız D. (2018a) ve Gezgin (2017)'in çalışmalarında da günlük mobil internet kullanım süresi ile nomofobi arasında pozitif ve anlamlı bir ilişkinin varlığı ortaya konulmuştur. Durak ve Seferoğlu (2018)'nun çalışmasında ise değişkenler arasında anlamlı farklılık bulunmuştur.

Mevcut literatürde nomofobik eğilimler üzerinde sosyal medyanın kullanım durumu ve özellikleriyle ilgili çalışmaların FoMO (Fear of Missing Out) olarak bilinen ve Türkçe alan yazına sosyal medyadaki gelişmeleri kaçırma korkusu olarak geçen bu fenomen tarafından etkilendiğini veya değişkenlerin birbirleriyle ilintili olduğunu raporlayan çalışmaların olduğu bilinmekte- 
dir. Facebook, Twitter, Instagram ve benzeri gibi daha pek çok sosyal ağ sitelerinin problemli kullanımı olarak bilinen FoMO'nun, nomofobi üzerindeki etkisini ortaya koyan çalışmaların birinde (Gezgin vd., 2018); ilgili değişkenler arasında orta düzeyde ve pozitif bir ilişki tespit edilmiştir. Ayrıca öğrencilerin nomofobi düzeylerinin yordanmasında problemli sosyal medya kullanımının \%41'lik bir etki gücüne sahip olduğu da hesaplanmıştır. Zira Kuss ve Griffiths (2017) de, akıllı telefon ve sosyal medya bağımlılığının nomofobi ile ilintili olduğunun altını çizmektedirler. Bu bağlamda Hoşgör vd. (2017b)'nin bulguları da bunu destekler niteliktedir. İlgili çalışmada; yanlarında sürekli şarj cihazı taşıyan, uyanır uyanmaz akıllı telefonlarını kontrol eden, yatağa akıllı telefonlarıyla giren, akıllı telefonlarını günde en az 50 defa kontrol eden, en az 7 yıldır bir sosyal medya hesabına sahip olan, akıllı telefonları üzerinden sosyal ağlara bağlanan, en az 4 farklı sosyal ağ sitesinde/uygulamasında üyeliği bulunan ve günde en az 7 saatini sosyal medyada geçiren öğrencilerin, FoMO'ya yatkın oldukları rapor edilmiştir.

Bir diğer taraftan bu çalışmada; öğrencilerin dersi derste dinleme/öğrenme ve derse katılım düzeyleri üzerinde nomofobi değişkeninin negatif ve anlamlı etkisi görülmüsstür. Ulusal ve uluslararası literatürde bu değişkenlerin çoğunlukla Genel Ağırlıklı Not Ortalaması (GANO) ile ele alındığı bilinmektedir. Buradan hareketle, öğrencilerin dersi derste dinleme ve derse katılım durumlarını içeren ders performanslarının, akademik performansları üzerine de olumlu veya olumsuz etki edebileceğini ifade etmek yanlış olmayacaktır. Nitekim Lee vd. (2014)'nin çalışmasında da; dersi derste dinleyerek öğrenme ve konuları pekiştirerek sınavlara hazırlanma sürecinde öğrencilerin, akıllı telefonlarının cazibesine kapılarak zaten kısıtlı olan zamanlarını verimli yönetemedikleri, bu sebeple de dersleri geçme noktasında stres yaşadıkları vurgulanmaktadır. Bu bağlamda çalışma bulgularının Erdem vd. (2016)'nin bulgularıyla (negatif yönlü ve anlamlı ilişki) örtüştüğü belirtilebilir. Hoşgör vd. (2017a)'nin çalışmasında ise nomofobi alt boyutlarından sadece çevrimiçi olamama boyutunun, öğrencilerin nomofobi düzeyleri üzerinde negatif ve anlamlı etkisi görülmüştür. Benzer şekilde Çelik ve Atilla (2018)'nın çalışmasında da, değişkenler arasında anlamlı bir farklılık olduğu rapor edilmiştir. Bu bulguların aksine, Emdadul Haque vd. (2017) tarafından 215 tıp fakültesi öğrencisinin katılımıyla gerçekleştirilen bir diğer çalışmada ise, öğrencilerin ders esnasında akıllı telefon kullanmasının dikkat kaybına 
yol açtı̆̆ı; fakat akademik performansları ile akıllı telefon kullanımları arasında anlamlı bir ilişkinin olmadığı sonucuna varılmıştır.

Çalışma kapsamında elde edilen sonuçlar; öğrencilerin sosyo-demografik özellikleri hariç olmak üzere, akıllı telefon ve sosyal medya kullanım özelliklerinin, nomofobi eğilimleri üzerinde orta düzeyde (\%30) bir etkiye sahip olduğunu göstermektedir. Bir diğer taraftan öğrencilerin nomofobi düzeylerinin, ders performansları üzerinde negatif yönde ve düşük düzeyde bir etkisi ortaya konulmuştur. Dersi derste dinleme düzeyi üzerinde yaklaşık \%22 olan olumsuz etkinin, derse katılım düzeyi üzerinde ise $\% 13$ olduğu sonucuna varılmıştır. Bu olumsuz etkinin düzeyi her ne kadar düşük saptanmış olsa da, konuyla ilgili önlemlerin alınması önem arz etmektedir. Bu bağlamda öğrencilerin ebeveynlerine, üniversite yönetimlerine ve akademisyenlere birtakım sorumluluklar düşmektedir. İlk olarak, nomofobinin önemli bir sorun olduğu ve ne gibi muhtemel etkileri olduğu hakkında ailelerin farkındalık düzeylerinin yükseltilmesi gündeme gelebilir. Yazılı ve görsel medya vasıtasıyla konuyla ilgili kamuoyu oluşturulabilir, kamu spotları devreye konulabilir. Böylelikle ebeveynlerin, küçük yaşlardan itibaren çocuklarını doğru yönlendirmeleri teşvik edilebilir. Bir diğer taraftan akademisyenler ve üniversite yönetimleri tarafından, öğrencilerin derslere ilişkin performanslarının ve ilgilenim düzeylerinin takibi ile verimliliklerinin iyileştirilmesi, hem kalifiye iş gücüne sahip olunması, hem de dolaylı açıdan Türkiye'nin dünya üniversiteleri ile rekabet edebilmesi açısından oldukça kritiktir. Bu bakımdan öğrencilerin ders dışı amaçlar için akıllı telefon kullanımlarının, derslere ilişkin konsantrasyon ve performans düzeylerini azaltabileceği gerekçesiyle, bazı önlemler alınarak en aza indirgenmesi önem arz etmektedir. Bu konuda üniversite yönetimlerince, derse girerken akıllı telefonların kapatılması yönünde caydırıcı bir politikanın benimsenmesi söz konusu olabilir. Fakat yasaklama ve cezalandırma gibi öğrencilerin nomofobi düzeylerini minimize etmeyi amaçlayan yönetsel politikaların uzun vadede çok da etkili olamayacağ aşikârdır. Bu bağlamda öğrencilerin derse yönelik amaçlar doğrultusunda mobil cihazlar ve internet kullanımının akademisyenler tarafından teşvik edilmesi ve konuyla ilgili öğrenci-akademisyen entegrasyonunun sağlanması faydalı olabilir. 


\title{
EXTENDED ABSTRACT
}

\section{The Factors Influencing Nomophobia Level of University Students and the Effect of Nomophobia on the Course Performances}

\author{
Haydar Hoşgör \\ Uşak University
}

In today's modern and digitalized world, anxiety is an inevitable source of stress in life. Nomophobia, known as a fear of being deprived of a smartphone, is a new concept added to the list of stressors. In other words, nomophobia introduced into the literature as a smartphone addiction is a result of technological developments that provide virtual communication (Pavithra et al., 2015, p.340). Especially technologically, mobile phones have become an indispensable part of the daily lives of individuals by making an extraordinary development in recent years (Ar-gumosa-Villar et al., 2017, p.127). Dasgupta et al. (2017, p.199) states that important technological developments and decreasing costs of smartphones have gradually increased mobile addiction worldwide.

In the "Digital in 2018" Report published annually by "We Are Social"; It is reported that $68 \%$ of the world population of approximately 7.6 billion uses smartphones, $53 \%$ of them use the internet, $42 \%$ use social media actively, and $39 \%$ connect to social media via their smartphones (We are Social, 2018). Also, these ratios are $90 \%, 67 \%, 63 \%, 54 \%$, respectively in Turkey. According to the Deloitte Times (2018) Report, mobile users in Turkey are checking to a smartphone in every 13 minutes. In other words, the Turkish people check their smartphones on average 78 times a day. As seen from these data, the vast majority of Turkey's population prone to nomophobic effects. Indeed, Kanmani et al. (2017, p.6) also state that millions of people worldwide suffer from nomophobia, and the group most affected by this is the young adolescents in the 18-24 age range.

Smartphones, which empower individuals to satisfy their basic needs, may cause some problems in addition to their obvious benefits (Yıldırım \& Correia, 2015, p. 130). In parallel, Alosaimi et al. (2016, p.676) also points out that; in addition to the many benefits of smartphones, such as easy access to 
information, social connectivity, and multiple communication environments, there are also health problems that are exposed to the use of such mobile devices. In the related study carried out with the participation of 2367 university students; as a result of using a smartphone, it was determined that $43 \%$ of the participants had fewer sleep hours and their energies decreased the next day, and $30 \%$ had an unhealthy lifestyle. Similarly, with the frequency of smartphone usage in the current literature; many studies are reporting that positive relationships are seen between mobile phone addiction, anxiety, stress, and depression (Roberts and Pirog, 2013; Nikhita et al., 2015; Billieux et al., 2015; Takao et al., 2009). It is known that nomophobia (Broughton, 2015), which negatively affects the daily life of the young generation, both physically and mentally, disrupts the finger structure, causes distraction, damages sleep quality and triggers alienation (King et al., 2013; Ming et al., 2006). Besides, Kwon et al. (2013, p.1) refer to the fact that children of primary school age can turn into smartphone addicts due to games and videos, and therefore a decrease in the course concentrations may occur.

Although there is a limited number of studies in the national literature, there are many studies in the international literature that deal with students' academic performance and nomophobia. For example, in a study conducted by Ahmed et al. (2019) with 157 physiotherapy students, a significant and negative relationship was found between academic performance and nomophobia. In a study conducted by Louragli et al. (2018) with 541 adolescents, a reverse relationship was found between nomophobia and school performance, and it was concluded that the role of smartphones in this relationship was more effective than notebook computers. In a study carried out with the participation of 308 female students studying medicine in Pakistan (Aman et al., 2015), it has been reported that $81 \%$ of students change their daily routines after receiving a smartphone and $53 \%$ of their academic performance is negatively affected. In a study carried out with the participation of 554 dentist candidates, by Prasad et al. (2017), approximately $39.5 \%$ of students stated that if they spend more time with their smartphones, they will get lower scores from professional exams.

In this study, it was aimed to determine the factors that affect the nomophobia levels of the students and the investigation of the effect of nomophobia on their lesson performances. The participants of this descriptive study con- 
sists of 258 students who are studying in different department related to health in Istanbul in the 2017-2018 academic year spring semester. In the data collection, the Nomophobia Questionnaire, which was developed by Y1ld1rım and Correia (2015) and adapted to Turkish by Yildırım et al. (2016), was used. In the data analysis, descriptive statistics, confirmatory factor analysis and structural equation model were used. The nomophobia levels of the students is calculated above the average $(3,20 \pm 0,81)$. It was determined that the variables of the frequency of the smartphone's daily control $(\beta=0,35)$, carrying the status of the charger $(\beta=-0,12)$, controlling the status of the smartphone as soon as waking up $(\beta=-0,29)$, and daily use time of social media using the smartphone $(\beta=0,15)$ were affecting the nomophobia levels of students significant. In other words, the nomophobia levels of the students were predicted with $30 \%$ rate by the qualities of the smartphone and social media usage. All pathways between the nomophobia latent variable and the observational variables constituting its sub-dimensions were also found to be positive and significant. There was a negative and significant effect of nomophobia on students' listening to the course $(\beta=-0.22)$ and its participation levels $(\beta=-0.13)$. In summary, as students' nomophobia levels increase, their course performances decrease.

\section{Kaynakça / References}

Adnan, M. ve Gezgin, D. M. (2016). Modern çağın yeni fobisi: üniversite öğrencileri arasında nomofobi prevalansı. Ankara Üniversitesi Eğitim Bilimleri Fakültesi Dergisi, 49(1), 141-158.

Ahmed, S., Pokhrel, N., Roy, S. ve Samuel, A. J. (2019). Impact of nomophobia: a non drugaddiction among students of physiotherapycourseusing an onlinecross-sectional survey. Indian Journal of Psychiatry, 61(1), 77-80.

Ak, Y. N. ve Yildırım, S. (2018). Nomophobia among undergraduatestudents: the case of a Turkish state university. International Journal on New Trends in Education and Their Implications, 9(4), 11-20.

Alosaimi, F. D., Alyahya, H., Alshahwan, H., Al Mahyijari, N. ve Shaik, S. A. (2016). Smartphone addiction among universitystudentsin Riyadh, Saudi Arabia. Saudi Medical Journal, 37(6), 675-683.

Altunışık, R., Coşkun, R., Bayraktaroğlu, S. ve Yıldırım, E. (2010). Sosyal bilimlerde araştırma yöntemleri: spss uygulamalı (6. baskı). Sakarya: Sakarya Yayıncilik. 
Aman, T., Shah, N., Hussain, A., Khan, A., Asif, S. ve Qazi, A. (2015). Effects of mobile phone use on the social and academic performance of students of a public sector medical college in Khyberpakhtunkhwa Pakistan. The Kaohsiung Journal of Medical Sciences, 8(1), 99-103.

Argumosa-Villar, L., Boada-Grau, J. ve Vigil-Colet, A. (2017). Exploratory investigation of theoretical predictors of nomophobia using the mobile phone involvement questionnaire (mpiq). Journal of Adolescence, 56, 127-135.

Billieux, J., Maurage, P., Lopez-Fernandez, O., Kuss, D. J. ve Griffiths, M. D. (2015). Can disordered mobile phoneuse be considered a behavioral addiction? An update on current evidence and a comprehensive model for future research. Current Addiction Reports, 2(2), 156-162.

Bragazzi, N. L. ve Del Puente, G. (2014). A proposal for including nomophobia in the new DSM-V. Psychology Research and Behavior Management, 7, 155-160.

Broughton, G. (2015). The changing face [book] of friendship, fellowship and formation. StMark's Review, 233, 74-86.

Burucuoğlu, M. (2017). Meslek yüksekokulu öğrencilerinin nomofobi düzeyleri üzerinde bir araştırma. Karabük Üniversitesi Sosyal Bilimler Enstitüsü Dergisi, 7(2), 482-489.

Büyükçolpan, H. (2019). Üniversite öğrencilerinde nomofobi, bă̆lanma biçimleri, depresyon ve algılanan sosyal destek Yayımlanmamış yüksek Lisans tezi. Hacettepe Üniversitesi/ Eğitim Bilimleri Enstitüsü, Ankara.

Campbell, S. W. (2004). Normative mobilephone use in public settings, Paper Presented at the Annual Meeting of the National Communication Association, Chicago, IL.

Choliz M. (2010). Mobile phone addiction: a point of issue.Addiction, 105(2),373374.

Çelik, Y. ve Atilla, G. (2018). Üniversite öğrencilerinin nomofobi, duygu düzenleme güçlüğü ve akademik başarıları arasındaki ilişkinin incelenmesi: Manavgat MYO örneği. Journal of Social and Humanities Sciences Research, 5(26), 2628-2639.

Dasgupta, P.,Bhattacherjee, S., Dasgupta, S., Roy, J. K., Mukherjee, A. ve Biswas, R. (2017). Nomophobic behaviors among smartphone using medical and engineering students in two colleges of Westbengal. Indian Journal of Public Health, 61, 199-204.

Davie, N. ve Hilber, T. (2017). Nomophobia: is smartphone addiction a genuine risk for mobile learning? 13th International Conference Mobile Learning, ISBN: 978-989-8533-61-6. 
Dikmen Y. (2016). Evaluation of the relationship between social level perceived as the predictor of academic achievement and solitude in nursing students. Journal of Human Sciences, 13(2), 3033-3043.

Durak, H. ve Seferoğlu, S. S. (2018). Ortaokul öğrencilerinin akıllı telefon kullanımları ve bağımlılık düzeyleriyle ilgili bir inceleme. Eğitim Teknolojisi Kuram ve Uygulama, 8(1), 1-23.

EmdadulHaque, A. T. M., Haque, M., Kibria, G. M., Fadzil, A. A. B., Hisham M. A. B. M., Mahamarowi, N. H. B., Yusri, N. I. S. B. M. ve Zalami, S. N. A. B. (2017). Usage of mobile applications at night and its association with sleep pattern and academic performance of the medical students of unikl-rcmp, ipoh, Malaysia. Journal of Global PharmaTechnology, 9(9), 15-24.

Erdem, H., Kalkın, G., Türen, U. ve Deniz, M. (2016). Üniversite öğrencilerinde mobil telefon yoksunluğu korkusunun (nomofobi) akademik başarıya etkisi. Süleyman Demirel Üniversitesi İktisadi ve İdari Bilimler Fakültesi Dergisi, 21(3), 923-936.

Erdem, H., Türen, U. ve Kalkın, G. (2017). Mobil telefon yoksunluğu korkusu (nomofobi) yayılımı: Türkiye'den üniversite öğrencileri ve kamu çalışanları örneklemi. Bilişim Teknolojileri Dergisi, 10(1), 1-12.

Farooqui, I. A., Pore, P. ve Gothankar, J. (2017). Nomophobia: an emerging issue in medical institutions? Journal of Mental Health, 1-4.

Gezgin, D. M. (2017). Exploring the influence of the patterns of mobile internet use on university students' nomophobia levels. European Journal of Education Studies, 3(6), 29-53.

Gezgin, D. M., Şahin, Y. L. ve Yıldırım, S. (2017). Sosyal ağ kullanıcılarının nomofobi düzeylerinin çeşitli faktörler açısından incelenmesi. Ĕ̆itim Teknolojisi Kuram ve Uygulama, 7(1), 1-15.

Gezgin, D. M. Hamutoğlu, N. B., Sezen-Gultekin, G. ve Gemikonakli, O. (2018). Relationship between nomophobia and fear of missing out among Turkish university students. Cypriot Journal of Educational Science, 13(4), 549-561.

Gezgin, D. M. ve Parlak, C. (2018). Kosova'da öğrenim gören öğrenciler arasında nomofobi yaygınlığı. International Balkan Education and Science Congress, 6-8 september, Trakya University, Edirne.

Gezgin D. M., Hamutoğlu, N. B., Sezen-Gültekin, G. ve Ayaş, T. (2018b). The relationship between nomophobia and loneliness among Turkish adolescents. International Journal of Research in Education and Science, 4(2),358-374. 
Gutiérrez-Puertas, L., Márquez-Hernández, V. V., São-Romão-Preto, L., Granados-Gámez, G., Gutiérrez-Puertas, V., ve Aguilera-Manrique, G. (2019). Comparative study of nomophobia among Spanish and Portuguese university students. Nurse Education in Practice, 34, 79-84.

Hair, J. F, Black W. C, Babin B. J, Anderson, R. E. ve Tahtam, R. L. (2006). Multivariate data analysis. New Jersey: Pearson PrenticeHall.

Hakkari, F. (2018). Meslek yüksekokulu öğrencilerinin nomofobi düzeylerinin belirlenmesi: Kırıkhan MYO örneği. Atlas International Referred Journal on Social Sciences, 4(10), 786-797.

Harish, B. R. ve Bharath, J. (2018). Prevalence of nomophobia among the under graduate medical students of mandya institute of medical sciences, mandya. International Journal of Community Medicine and Public Health, 5(12), 5455-5459.

Hoşgör, H., Tandoğan, Ö. ve Gündüz Hoşgör, D. (2017a). Nomofobinin günlük akıllı telefon kullanım süresi ve okul başarısı üzerindeki etkisi: sağlık personeli adayları örneği. Akademik Sosyal Araştırmalar Dergisi, 5(46), 573-595.

Hoşgör, H., Koç Tütüncü, S., Gündüz Hoşgör, D. ve Tandoğan, Ö. (2017b). Üniversite öğrencileri arasında sosyal medyadaki gelişmeleri kaçırma korkusu yaygınlığının farklı değişkenler açısından incelenmesi, International Journal of Academic Value Studies, 3(17), 213-223.

Kanmani, A., Bhavani, U., Maragatham, R. S. (2017). Nomophobia-an insight into its psychological aspects in India. International Journal of Indian Psychology, 4(2), 5-15.

King, A.L., Valença, A. M., Silva, A. C., Sancassiani, F., Machado, S. ve Nardi, A. E. (2014) Nomophobia: impact of cell phone use interfering with symptoms and emotions of individuals with panic disorder compared with a control group. Clinical Practice and Epidemiology in Mental Health, 10, 28-35.

King, A. L., Valença, A. M. ve Nardi, A. E. (2010). Nomophobia: the mobile phone in panic disorder with agoraphobia: reducing phobias or worsening of dependence? Cognitive and Behavioral Neurology, 23(1), 52-54.

King, A. L., Valença, A. M., Silva, A. C., Baczynski, T., Carvalho, M. R. ve Nardi, A. E. (2013). Nomophobia: dependency on virtual environments or social phobia? Computers in Human Behavior, 29(1), 140-144.

Kocabaş, D. ve Korucu, S. (2018). Dijital çağın hastalığı nomofobi üzerine bir araştırma. Avrasya Sosyal ve Ekonomi Araştırmaları Dergisi, 5(11), 254-268. 
Kuss, D. J. ve Griffiths, M. D. (2017). Social networking sites and addiction: ten lessons learned. International Journal of Environmental Research and Public Health, 14(3), 311.

Kwon, M., Lee, J. Y., Won, W. Y., Park J. W, Min, J. A. ve Hahn, C. (2013). Development and validation of a smartphone addiction scale (sas). PloS One, 8(2), 1-7.

Lee, Y. K., Chang, C. T., Lin, Y. ve Cheng, Z. H. (2014). The darkside of smartphone usage: psychological traits, compulsive behavior and techno stress. Computers in Human Behavior, 31, 373-383.

Louragli, I., Ahami, A., Khadmaoui, A., Mammad, K. ve Lamrani, A. C. (2018). Evaluation of the nomophobia's prevalence and its impact on schools performance among adolescents in Morocco. Problems of Psychology in the 21st Century, 12(2), 84-94.

Mendoza, J. S., Pody, B. C., Lee, S., Kim, M. ve McDonough, I. M. (2018). The effect of cellphones on attention and learning: the influences of time, distraction, and nomophobia. Computers in Human Behavior, 86, 52-60.

Ming, Z., Pietikainen, S. ve Hänninen, O. (2006). Excessive texting in pathophysiology of first carpometacarpal joint arthritis. Pathophysiology, 13(4), 269-270.

Nikhita, C. S., Jadhav, P. R. ve Ajinkya, S. A. (2015). Prevalence of mobile phone dependence in secondary schools adolescents. Journal Clinical Diagnostic Research, 35(2), 339-341.

Öz, H. ve Tortop, H. S. (2018). Üniversite okuyan genç yetişkinlerin mobil telefon yoksunluğu korkusu (nomofobi) ile kişilik tipleri arasındaki ilişkinin incelenmesi. Yeni Medya Elektronik Dergisi, 2(3), 146-159.

Pavithra, M. B., Suwarna, M. ve Mahadeva Murthy, T. S. (2015). A study on nomophobia-mobile phone dependence, among students of a medical college in Bangalore. National Journal of Community Medicine, 6(3), 340-344.

Prasad, M., Patthi, B., Singla, A., Gupta, R., Saha, S., Kumar, J. K., Malhi, R. ve Pandita, V. (2017). Nomophobia: across-sectional study to assess mobile phone usage among dental students. Journal of Clinical and Diagnostic Research, 11(2), 34-39.

Roberts, J. ve Pirog, S. (2013). A preliminary investigation of materialism and impulsiveness as predictors of technological addictions among young adults. Lournal of Behavioral Addictions, 2(1), 56-62. 
Rosales-Huamani, J. A., Guzman-Lopez, R. R., Aroni-Vilca, E. E., Matos-Avalos, C. R. ve Castillo-Sequera, J. L. (2019). Determining symptomatic factors of nomophobia in Peruvian students from the national university of engineering. Preprints, 2019010331.

Sert, H., Taşkın Yılmaz, F., Karakoç Kumsar, A. ve Aygin, D. (2019). Effect of technology addiction on academic success and fatigue among Turkish university students. Fatigue: Biomedicine, Health \& Behavior, 1-11.

Sethia, S., Melwani, V., Melwani, S., Priya, A., Gupta, M. ve Khan, A. (2018). A study to assess the degree of nomophobia among the undergraduate students of a medical college in Bhopal. International Journal of Community Medicine and Public Health, 5(6), 2442-2445.

Sırakaya, M. (2018). Önlisans öğrencilerinin nomofobi düzeylerinin akıllı telefon kullanım durumlarına göre incelenmesi. Mersin Üniversitesi Ĕ̆itim Fakültesi Dergisi, 14(2), 714-727.

Tabachnick, B. G. ve Fidell, L. S. (2007). Experimental designs using ANOVA. Thomson/Brooks/Cole.

Takao, M., Takahashi, S. ve Kitamura, M. (2009). Addictive personality and problematic mobile phoneuse. Cyber Psychology E Behavior, 12(5), 501-507.

The Deloitte Times (2018). Retrieved 01 March, 2018, from https://www2.deloitte.com/content/dam/Deloitte/tr/Documents/thedeloitte-times/TDT Subat\%202018 GMCS.pdf

Uysal, Ş., Özen, H. ve Madenoğlu, C. (2016). Social phobia in higher education: the influence of nomophobia on social phobia. The Global e-learning Journal, 5(2), 1-8.

Ünal, M. H. (2015). Ankara yıldırım beyazıt üniversitesi tıp fakültesi öğrencilerinin akıllı telefon bă̆ımlılık düzeylerinin belirlenmesi. Yayımlanmamış uzmanlık tezi. Yıldırım Beyazıt Üniversitesi/Tıp Fakültesi, Ankara.

Wallace, P. (2014). Internet addiction disorder and youth: there are growing concerns about compulsive online activity and that this could impede students' performance and social lives. EMBO reports, 15(1), 12-16.

We are Social (2018). Special reports: digital in 2018: globaloverview. Retrieved 01 March, 2018, from https://wearesocial.com/blog/2018/01/global-digital-report-2018

Yıldırım, S. ve Kişioğlu, A. N. (2018). Teknolojinin getirdiği yeni hastalıklar: nomofobi, netlessfobi, fomo. Süleyman Demirel Üniversitesi Tıp Fakültesi Dergisi, 25(4), 473-480. 
Ylldiz D, H. (2018a). What would you do without your smartphone? Adolescents' social media usage, locus of control, and loneliness as a predictor of nomophobia. Addicta: The Turkish Journal on Addictions, 5(2), 151-163.

Yıldız D, H. (2018b). Investigation of nomophobia and smartphone addiction predictors among adolescents in Turkey: demographic variables and academic performance. The Social Science Journal, https://doi.org/10.1016/j.soscij.2018.09.003

Yıldırım, A. (2017). The relationship between empathic tendencies and nomophobia of prospective teachers. New Trends and IssuesProceedings on Humanities and Social Sciences, 4(3), 136-141.

Yıldırım, C., Sumuer, E., Adnan, M. ve Yıldırım, S. (2016). A growing fear: prevalence of nomophobia among Turkish college students. Information Development, 32(5), 1322-1331.

Yıldırım, C. ve Correia, A. P. (2015). Exploring the dimensions of nomophobia: development and validation of a self-reported questionnaire. Computers in Human Behavior, 49, 130-137.

Yoğurtçu, D. D. (2018). The relationship between five factor personality traits and nomophobia levels among university students Unpublished master thesis. Yeditepe University/Institute of Educational Sciences, Istanbul.

Yorulmaz, M., Kıraç, R. ve Sabırlı, H. (2018). Üniversite öğrencilerinde nomofobinin uyku ertelemeye etkisi. Journal of Social and Humanities Sciences Research, 5(27), 2988-2996.

\section{Kaynakça Bilgisi / Citation Information}

Hoşgör, H. (2020). Üniversite öğrencilerinin nomofobi düzeyinietkileyen faktörler ve ders performansları üzerinde nomofobinin etkisi. OPUS-Uluslararası Toplum Araştırmaları Dergisi, 15(25), 3167-3198. DOI: 10.26466/opus.650312 